\title{
Mineralization in a northeastern Greenland sediment: mathematical modelling, measured sediment pore water profiles and actual activities
}

\author{
Søren Rysgaard ${ }^{1, *}$, Peter Berg ${ }^{2}$ \\ ${ }^{1}$ National Environmental Research Institute, Vejlsøvej 25, DK-8600 Silkeborg, Denmark \\ ${ }^{2}$ University of Virginia, Clark Hall, Dept of Environmental Sciences, Charlottesville, Virginia 22903, USA
}

\begin{abstract}
A mathematical computer model describing mineralization processes and transport of solutes within sediments was developed based on the degradation of organic matter, stoichiometrically coupled to the consumption of $\mathrm{O}_{2}$ in the oxic layers, and to $\mathrm{NO}_{3}{ }^{-}$and $\mathrm{SO}_{4}{ }^{2-}$ in the anoxic layers. The reaction rates obey Michaelis-Menten type kinetics and all transport of solutes is assumed to take place by diffusion. The model was tested on a northeastern Greenland sediment and gave accurate simulations of the measured concentration profiles. In addition, measured processes of nitrification, coupled nitrification-denitrification, denitrification of water column $\mathrm{NO}_{3}{ }^{-}, \mathrm{NH}_{4}{ }^{+}$mineralization and the fluxes of $\mathrm{NH}_{4}{ }^{+}$and $\mathrm{NO}_{3}{ }^{-}$across the sediment-water interface were predicted with great accuracy. Since the model is based on Michaelis-Menten type kinetics and diffusional transport mechanisms, it is of general use and provides an important tool to evaluate the regulation of biogeochemical cycling in sediments. This is shown in a series of simulations predicting the effect of various concentrations in the water column of $\mathrm{O}_{2}$ and $\mathrm{NO}_{3}{ }^{-}$on the rates of nitrification and denitrification. The results are in good agreement with previously published measurements.
\end{abstract}

KEY WORDS: Nitrogen Mineralization - Modelling · Denitrification Pore water

\section{INTRODUCTION}

A wide range of mathematical models concerning biogeochemical processes in sediments have been developed over the last several decades in which the transport of solutes takes place by diffusion. Some models have only included the transport of 1 solute, typically $\mathrm{O}_{2}$ (Revsbech et al. 1986, Dalsgaard \& Revsbech 1992, Rasmussen \& Jørgensen 1992). By prescribing different $\mathrm{O}_{2}$ consumption at specified depths and then by continuous simulations matching calculated and measured $\mathrm{O}_{2}$ profiles, these models have estimated $\mathrm{O}_{2}$ consumption as function of depth. Other models have been more complex and have more or less included the interaction of different solutes (Vanderborght \& Billen 1975, Billen 1982, Jahnke et al. 1982, Boudreau et al. 1992). These models are based

\footnotetext{
•E-mail: sI@dmu.dk
}

on analytical solutions of the governing differential equations. Restrictive assumptions such as constant porosity, diffusivity and molar $\mathrm{C}: \mathrm{N}$ ratio of organic matter with sediment depth must be made in order to make these analytical solutions possible. It is also necessary to prescribe zones of activities such as $\mathrm{O}_{2}$ consumption as input parameters in order to find a solution. Only a limited number of solutes can be involved in these analytical solutions, and the flexibility of choosing different relations for reaction rates is very low. It was a step forward to apply numerical methods to the solution of the governing equations in multisolute sediment systems (Blackburn \& Blackburn 1993). These simulations of steady-state solutions include realistic variations of parameters such as porosity, diffusivity and the molar $\mathrm{C}: \mathrm{N}$ ratio of organic matter. Blackburn et al. (1994) used numerical methods to simulate successfully 2 concentration profiles $\left(\mathrm{O}_{2}\right.$ and $\left.\mathrm{NO}_{3}{ }^{-}\right)$, as well as the rates of nitrification and denitrification in freshwater sediments. A major draw- 
back using this model is that almost an entire day of calculation time is required before a steady-state solution is obtained.

In the present study, our purpose was to develop a model that is capable of predicting concentration profiles of $\mathrm{O}_{2}, \mathrm{NO}_{3}{ }^{-}, \mathrm{NH}_{4}{ }^{+}$, and $\mathrm{CO}_{2}$ and their sedimentwater exchange rates by simulating the biogeochemical interactions between, as well as the transport of, these solutes. The biogeochemical reactions included in the model are based on the composition and quality of organic matter and they express the degradation of organic matter to $\mathrm{NH}_{4}{ }^{+}$and $\mathrm{CO}_{2}$. This degradation is stoichiometrically coupled to the consumption of $\mathrm{O}_{2}$ in the oxic layers and to $\mathrm{NO}_{3}{ }^{-}$and $\mathrm{SO}_{4}{ }^{2-}$ in the anoxic layers. For the purpose of generality, we have aspired to express all biogeochemical reaction rates only as functions of the actual simulated concentrations. In this way, the location and size of the production and consumption zones will automatically be calculated as a part of the solution, rather than being specified as input parameters. These reaction rates obey approximations of Michaelis-Menten kinetics. The transport of all 6 solutes included in the model $\left(\mathrm{O}_{2}, \mathrm{NO}_{3}{ }^{-}, \mathrm{NH}_{4}{ }^{+}\right.$, $\mathrm{CO}_{2}, \mathrm{~N}_{2}$, and $\mathrm{H}_{2} \mathrm{~S}$ ) is described by Fick's second law of diffusion, which makes both dynamic and steady-state simulations possible. With a well-balanced choice of numerical procedures, simulations can be done on a regular personal computer without the need for excessive calculation time. The model is tested on sediment cores from Young Sound, Greenland (Rysgaard et al. 1996).

\section{MATERIAL AND METHODS}

Biogeochemical background for the model. The decomposition of organic matter in sediments takes place under both oxic and anoxic conditions. Assuming that, on average, the oxidation state of carbon is that of carbohydrate $\left(\mathrm{CH}_{2} \mathrm{O}\right)$, the bound nitrogen is the amino form, and the oxidation state of phosphorus is that of orthophosphoric acid, Richards (1965) formulated the composition of organic matter as $\left(\mathrm{CH}_{2} \mathrm{O}\right)_{106}\left(\mathrm{NH}_{3}\right)_{16}$ $\mathrm{H}_{3} \mathrm{PO}_{4}$. Richards (1965) also suggested that mineralization of organic matter in oceanic sediments is stoichiometncally coupled to the consumption of $\mathrm{O}_{2}$ in oxic layers and to $\mathrm{NO}_{3}{ }^{-}$and $\mathrm{SO}_{4}{ }^{2-}$ in anoxic layers, and can be expressed as:

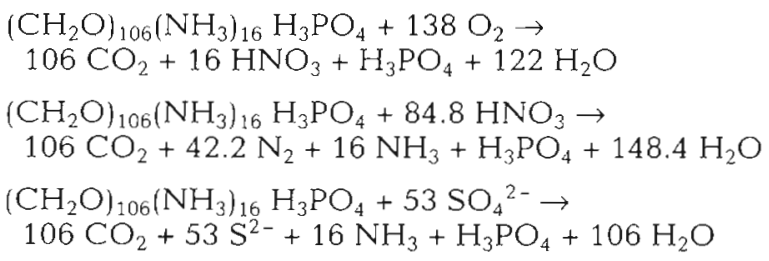

According to these reactions, the concentration profiles of $\mathrm{O}_{2}, \mathrm{NH}_{4}{ }^{+}, \mathrm{NO}_{3}{ }^{-}$and $\mathrm{TCO}_{2}\left(\mathrm{CO}_{2}, \mathrm{HCO}_{3}{ }^{-}, \mathrm{CO}_{3}{ }^{2-}\right)$ within the sediments are the result of mineralization processes. The average C: N:P ratio used in these reactions was the fixed Redfield ratio of 106:16:1 (Flemming 1940). However, sedimenting detritus shows a preferential depletion of nitrogen and phosphorus during the early stages of decomposition, and thus the $\mathrm{C}: \mathrm{N}: \mathrm{P}$ ratio in the organic matter being mineralized will not be constant with sediment depth (Blackburn 1980). A variable $C: N$ ratio with depth is therefore included in our model.

A modification of the reactions given by Eqs. (1) through (3) was made without changing the stoichiometric relationship between carbon, nitrogen, oxygen and sulfate. Oxidation of organic matter by $\mathrm{O}_{2}$ is described by 2 separate reactions: first the oxidation of organic matter (Org-M) to $\mathrm{NH}_{4}{ }^{+}$(Eq. 4), and second the oxidation of $\mathrm{NH}_{4}{ }^{+}$to $\mathrm{NO}_{3}{ }^{-}$by nitrifying bacteria (Eq. 5):

$$
\begin{gathered}
\text { Org- } \mathrm{M}+\mathrm{O}_{2} \stackrel{v_{1}}{\longrightarrow} \mathrm{CO}_{2}+\frac{1}{\mathrm{C}: \mathrm{N}} \mathrm{NH}_{4}{ }^{+} \\
\mathrm{NH}_{4}{ }^{+}+2 \mathrm{O}_{2} \stackrel{v_{2}}{\longrightarrow} \mathrm{NO}_{3}{ }^{-} \mathrm{n}
\end{gathered}
$$

where $V_{1}$ and $V_{2}$ are the rates at which the solutes on the right of the equations are produced, and $C: N$ is the ratio of the organic matter being oxidized.

The oxidation of organic matter with $\mathrm{NO}_{3}{ }^{-}$is also divided into 2 reactions to separate the effect of $\mathrm{NO}_{3}{ }^{-}$ produced by nitrification in the sediment and $\mathrm{NO}_{3}{ }^{-}$ supplied from the water column:

Org-M $+2 \mathrm{NO}_{3}{ }^{-} \stackrel{\mathrm{n}}{3}_{\longrightarrow} 2.5 \mathrm{CO}_{2}{ }^{-}+\frac{2.5}{\mathrm{C}: \mathrm{N}} \mathrm{NH}_{4}{ }^{+}+\mathrm{N}_{2}$

Org-M $+2 \mathrm{NO}_{3}{ }^{-}{ }^{w} \stackrel{v_{4}}{\longrightarrow} 2.5 \mathrm{CO}_{2}{ }^{-}+\frac{2.5}{\mathrm{C}: \mathrm{N}} \mathrm{NH}_{4}{ }^{+}+\mathrm{N}_{2}$

This separation is important because it enables the model to distinguish between coupled nitrificationdenitrification and denitrification based on water column $\mathrm{NO}_{3}{ }^{-}$. This is highly relevant in studies where rates of denitrification have to be related to external loading of nitrogen and/or to internal sources of nitrogen.

Finally, the oxidation of organic matter by $\mathrm{SO}_{4}{ }^{2-}$ is described as:

$$
\mathrm{Org}-\mathrm{M}+\mathrm{SO}_{4}{ }^{2-} \stackrel{v_{3}}{\longrightarrow} 2 \mathrm{CO}_{2}+\frac{2}{\mathrm{C}: \mathrm{N}} \mathrm{NH}_{4}{ }^{+}+\mathrm{H}_{2} \mathrm{~S}
$$

and the reoxidation of $\mathrm{H}_{2} \mathrm{~S}$ (or more accurately the reoxidation of reducing equivalents from sulfate reduction) is described as:

$$
\mathrm{H}_{2} \mathrm{~S}+2 \mathrm{O}_{2} \stackrel{V_{6}}{\longrightarrow} \mathrm{SO}_{4}^{2-}+2 \mathrm{H}^{+}
$$


The reactions given in Eqs. (4) through (9) represent the fundamental processes in the model. The rate at which $\mathrm{H}_{2} \mathrm{~S}$ is produced, $V_{5}$, is defined as an input parameter. The additional rates, $V_{1}, V_{2}, V_{3}, V_{4}$, and $V_{6}$, are all expressed as a function of the concentration of the precursors only. As described below, approximations of Michaelis-Menten kinetics are used for this purpose.

Mathematical formulation of the model. Assuming that all spatial transport of solutes in the sediment takes place by 1-dimensional diffusion, the transport process is described by Fick's second law of diffusion (Berner 1980). Adding a term that represents production leads to

$$
\frac{\delta C}{\delta t}=D_{\mathrm{s}} \frac{\delta^{2} C}{\delta x^{2}}+\left[\frac{\delta D_{\mathrm{s}}}{\delta x}+\frac{D_{\mathrm{s}}}{\varphi} \frac{\delta \varphi}{\delta x}\right] \frac{\delta C}{\delta x}+\frac{P}{\varphi}
$$

where $C$ is the concentration in the pore water, $t$ is the time, $x$ is the depth, $D_{\mathrm{s}}$ is the sediment diffusion coefficient, $\varphi$ is the porosity, and $P$ is the rate of production (or consumption if $P$ is negative) per unit volume of sediment. This formulation includes heterogeneous substrates where $D_{\mathrm{s}}$ and $\varphi$ vary with depth. Eq. (10) can be rewritten as follows:

$$
\varphi \frac{\delta C}{\delta t}=-\frac{\delta J}{\delta x}+P
$$

where $J$ is the diffusive flux given by Fick's first law of diffusion:

$$
J=-\varphi D_{s} \frac{\delta C}{\delta x}
$$

The sediment diffusion coefficient, $D_{\mathrm{s}}$, is expressed as a function of porosity according to Ullman \& Aller (1982). For sediment layers with $\varphi \leq 0.7$ they recommend:

$$
D_{\mathrm{s}}=D \varphi
$$

where $D=$ the molecular diffusion coefficient in seawater. Combining Eqs. (11), (12) \& (13) gives the following general equation for the diffusional transport of an arbitrary solute:

$$
\varphi \frac{\delta C}{\delta t}=D \frac{\delta}{\delta x}\left[\varphi^{2} \frac{\delta C}{\delta x}\right]+P
$$

This governing equation will be solved by applying a numerical technique. It is important to note that this rewriting of Eq. (10) is not a ssimplification of the equation, but a more compact differential formulation that gives some advantages in the numerical solution of the equation. The numerical procedure becomes more simple and results in a considerable reduction in simulation time. Eq. (14) is used to describe the transport of all components included in the model $\left(\mathrm{O}_{2}, \mathrm{NO}_{3}^{-} \mathrm{n}\right.$. $\mathrm{NO}_{3}{ }^{-}, \mathrm{NH}_{4}{ }^{+}, \mathrm{CO}_{2}, \mathrm{~N}_{2}$, and $\mathrm{H}_{2} \mathrm{~S}$ ).

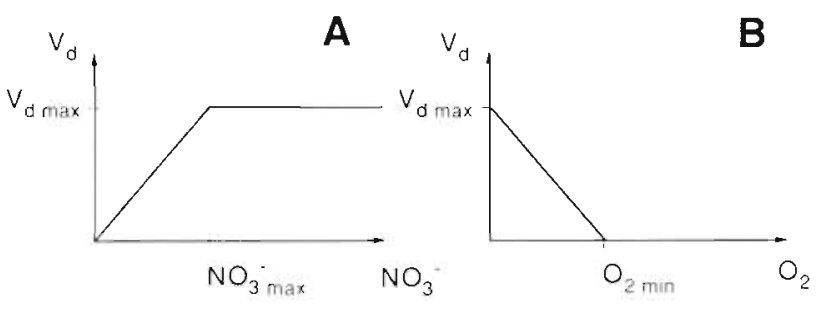

Fig. 1 Total activity of denitrification $\left(V_{d}\right)$ as a function of (A) $\mathrm{NO}_{3}{ }^{-}$concentration and $(\mathrm{B}) \mathrm{O}_{2}$ concentration

The transport of $\mathrm{NO}_{3}{ }^{-}$is divided into 2 fractions; one that diffuses down into the sediment from the overlying water $\left(\mathrm{NO}_{3}{ }^{-} \mathrm{w}\right)$, and one that is produced by nitrification within the sediment $\left(\mathrm{NO}_{3}^{-}{ }_{n}\right)$. Using this distinction, the model can simulate actual measured rates of denitrification based on $\mathrm{NO}_{3}^{-}$from the overlying water and denitrification coupled to nitrification within the sediment. The total denitrification activity $\left(V_{\mathrm{d}}\right)$ must be calculated as 1 rate, and then divided into the 2 components $V_{3}$ and $V_{4}$ (Eqs. $6 \& 7$ ). It is assumed that $V_{\mathrm{d}}$ is regulated by the total $\mathrm{NO}_{3}{ }^{-}$concentration $\left(\mathrm{NO}_{3}{ }_{n}{ }^{-}+\right.$ $\mathrm{NO}_{3}{ }^{-} \mathrm{w}$ ), as well as by the $\mathrm{O}_{2}$ concentration as shown in Fig. 1, where $V_{\text {d max }}, \mathrm{NO}_{3}^{-}$max , and $\mathrm{O}_{2}$ min are known input parameters describing the line segments shown. Denitrification activity is stimulated by $\mathrm{NO}_{3}{ }^{-}$until a maximum rate $\left(V_{\mathrm{d} \text { max }}\right)$ is obtained, following an approximation of Michaelis-Menten kinetics (Fig. 1A). In contrast, the rate of denitrification is inhibited by the presence of $\mathrm{O}_{2}$ (Fig. 1B), and for $\mathrm{O}_{2}$ concentrations greater than $\mathrm{O}_{2}$ mın the denitrification activity is zero. The magnitude of $V_{\mathrm{d}}$ is determined by calculating 2 values, one as a function of the $\mathrm{NO}_{3}{ }^{-}$concentration (Fig. 1A), and one as a function of the $\mathrm{O}_{2}$ concentration (Fig. 1B), and then choosing the smaller of the 2 values. This can be expressed efficiently by using the functions MIN and MAX, which are standard functions in most programming languages. The calculation is carried out in 2 steps:

$$
\begin{aligned}
& V_{\mathrm{d}}=\operatorname{MIN}\left[\frac{V_{\mathrm{d} \max }}{\mathrm{NO}_{3}^{-} \mathrm{NO}_{\max }} \mathrm{NO}^{-}, V_{\mathrm{d} \max }-\frac{V_{\mathrm{d} \max }}{\mathrm{O}_{2 \min }} \mathrm{O}_{2}, V_{\mathrm{d} \max }\right] \\
& V_{\mathrm{d}}=\operatorname{MAX}\left[V_{\mathrm{d}}, 0\right]
\end{aligned}
$$

The function MIN (Eq. 15a) states that a value is calculated for each of the 3 arguments, and the smallest value given for $V_{\mathrm{d}}$ is used in further calculations. The first and third arguments in the function MIN represent the 2 line segments in Fig. $1 \mathrm{~A}$, and the second argument represents the descending line segment in Fig. 1B. The function MAX (Eq. 15b) is used to avoid the negative values of $V_{\mathrm{d}}$ that can be calculated from Eq. (15a) for $\mathrm{O}_{2}$ concentrations greater than $\mathrm{O}_{2}$ min. The 2 components, $V_{3}$ and $V_{4}$, are then calculated by: 


$$
\begin{aligned}
V_{3} & =\frac{\mathrm{NO}_{3}^{-} \mathrm{n}}{\mathrm{NO}_{3}{ }_{\mathrm{n}}+\mathrm{NO}_{3}^{-} \mathrm{w}} V_{\mathrm{d}} \\
V_{4} & =\frac{\mathrm{NO}_{3}{ }_{\mathrm{w}}}{\mathrm{NO}_{3}^{-}{ }_{\mathrm{n}}+\mathrm{NO}_{3}^{-} \mathrm{w}} V_{\mathrm{d}}
\end{aligned}
$$

The rate of nitrification, $V_{2}$, is related to the $\mathrm{NH}_{4}{ }^{+}$and $\mathrm{O}_{2}$ concentrations, but with a functional relationship as shown in Fig. $1 \mathrm{~A}$ for both concentrations:

$$
V_{2}=\operatorname{MIN}\left[\frac{V_{2 \max }}{\mathrm{NH}_{4}{ }^{+} \max }-\mathrm{NH}_{4}{ }^{+}, \frac{V_{2 \max }}{\mathrm{O}_{2 \max }} \mathrm{O}_{2}, V_{2 \max }\right]
$$

The rate of sulfide oxidation, $V_{6}$, is expressed similarly as a function of the $\mathrm{H}_{2} \mathrm{~S}$ and $\mathrm{O}_{2}$ concentrations:

$$
V_{6}-\operatorname{MiN}\left[\frac{V_{6} \max }{\mathrm{H}_{2} \mathrm{~S}_{\max }} \mathrm{H}_{2} \mathrm{~S}, \frac{V_{6} \max }{\mathrm{O}_{2 \max }} \mathrm{O}_{2}, V_{6 \max }\right]
$$

The rate of oxygen consumption by decomposing organic matter, $V_{1}$ is only related to the $O_{2}$ concentration with the functional relationship as shown in Fig. $1 \mathrm{~A}$ :

$$
V_{1}=\operatorname{MIN}\left[\frac{V_{1 \max }}{\mathrm{O}_{2 \max }} \cdot \mathrm{O}_{2}, V_{1 \max }\right]
$$

Using the reaction schemes given in Eqs. (4) through (9), the production term in Eq. (14) for each of the 7 components considered can be expressed as a function of $V_{1}$ through $V_{6}$ :

$$
\begin{aligned}
& \mathrm{O}_{2}: \quad P=-V_{1}-2 V_{2}-2 V_{6} \\
& \mathrm{NH}_{4}{ }^{+}: \quad P=\frac{1}{\mathrm{C}: \mathrm{N}} V_{1}-V_{2}+\frac{2.5}{\mathrm{C}: \mathrm{N}} V_{3}+ \\
& \frac{2.5}{C: N} V_{4}+\frac{2}{C: N} V_{5} \\
& \mathrm{NO}_{3}{ }^{-}: \quad P=-2 V_{4} \\
& \mathrm{NO}_{3}{ }^{-} \mathrm{n}: \quad P=V_{2}-2 V_{3} \\
& \mathrm{~N}_{2}: \quad P=V_{3}+V_{4} \\
& \mathrm{CO}_{2}: \quad P=V_{1}+2.5 V_{3}+2.5 V_{4}+2 V_{5} \\
& \mathrm{H}_{2} \mathrm{~S}: \quad P=V_{5}-V_{6}
\end{aligned}
$$

The transport equation (Eq. 14) used for each of the 7 components, combined with the reaction rates (Eqs. 15 through 20) and the production terms (Eqs. 21 through 27), constitute the mathematical formulation of the model.

Since an analytical solution of the transport equation is not possible, a solution must be found by using a numerical technique. In our implementation, we have derived a numerical solution of Eq. (14) by using an explicit control volume approach described by Patankar (1980). This approach is based on the spatial separation of both the diffusive boundary layer in the water and the underlying sediment core into control volumes (thin horizontal layers). The approach leads to the following general discretization equation:

$$
\begin{aligned}
& \varphi_{j} \frac{C_{j}^{n+1}-C_{j}^{n}}{\Delta t}= \\
& \frac{D}{\Delta x_{j}}\left(\varphi_{j+1 / 2}^{2} \frac{C_{j+1}^{n}-C_{j}^{n}}{\frac{1}{2}\left(\Delta x_{j}+\Delta x_{j+1}\right)}-\varphi_{j-1 / 2}^{2} \frac{C_{j}^{n}-C_{j-1}^{n}}{\frac{1}{2}\left(\Delta x_{j-1}+\Delta x_{j}\right)} \cdot+P_{j}\right.
\end{aligned}
$$

where index $j$ refers to the number of the control volume, $\Delta x_{j}$ is the size of control volume number $j$, and $\Delta t$ is the time step between time level $n$ and $n+1$. All concentrations are known at time level $n$. Due to the explicit element in the numerical solution, a well-defined upper limit for time step exists and using larger time steps will result in numerical instability in the procedure. This criterion can be expressed as

$$
\Delta t<\frac{\Delta x^{2}}{2 \varphi D}
$$

and it must be fulfilled for all control volumes and their related values of $\varphi D$.

The transient element in the discretized transport equation (Eq. 28) is a central part in this dynamic model, and involves the following procedure in every time step. As a starting point, all concentrations for all control volumes are known at time level $n$. Based on the known concentrations, new values of $V_{1}, V_{2}, V_{3}, V_{4}$, and $V_{6}$ are calculated (Eqs. 15 through 20 ) for all control volumes. Then a production term is calculated (Eqs. 21 through 27) for each control volume and for each of the 7 components included. With these production terms and the known concentrations at time level $n$, new concentrations are calculated (Eq. 28) at time level $n+1$ for all control volumes and solutes included. Measured concentrations for the different solutes are used as upper and lower boundary conditions in Eq. (28).

An adequate separation of both the diffusive boundary layer and the underlying sediment into control volumes must be specified as input to the model. It is important that the number of control volumes is large enough to ensure that the discretized transport equation (Eq. 28) is a good approximation of the differential transport equation (Eq. 14). A recommended test that addresses this issue is described below. In addition, diffusivities for the different solutes in seawater must be given as input, together with vaiues for porosity and the $C: N$ ratio as a function of depth. Furthermore, the rate $V_{5}$ at which $\mathrm{H}_{2} \mathrm{~S}$ is produced must be specified as well as values for the parameters ( $V_{d \text { max. }} \mathrm{NO}_{3}^{-}$max, $\mathrm{O}_{2 \text { max }}$, etc.) that describe the variation of the process rates $V_{1}, V_{2}, V_{3}, V_{4}$, and $V_{6}$. Finally, an adequate time step must be chosen, and known concentrations must be specified as boundary conditions for the uppermost control volume above the diffusive boundary layer and for the lowest control volume in the sediment. 
In this study we only deal with steady-state solutions, which are obtained by prescribing boundary conditions that are constant in time and then running the model until a stationary solution is achieved. This is defined as the point in time at which the fluxes in and out of the sediment equal the internal production of all components

All the presented simulations concern sediment cores with a depth of $10 \mathrm{~cm}$. In the upper $\mathrm{cm}$ of the sediment, where the variation in the diffusive profiles is largest, a uniform size of control volumes $(0.03 \mathrm{~cm})$ is used. Below this zone, where the profiles are more smooth, the control volume size is gradually increased by a factor of $1.1\left(\Delta x_{j}=1.1 \Delta x_{j-1}\right)$. The total number of control volumes is maintained at 66 by this scaling procedure. All simulations are carried out with a time step of $36 \mathrm{~s}$, which equals $95 \%$ of the critical time step. These resolutions in time and depth give a rather short simulation time of approximately $4 \mathrm{~s} \mathrm{~d}^{-1}$ using a Pentium/90 $\mathrm{MHz}$ personal computer. In order to guarantee that the presented simulations are accurate solutions of the governing mathematical equations, additional simulations were carried out with a finer resolution in both time and space. Reducing the size of the control volumes by a factor of 2 and the time step by a factor of 4 gave the same results within $1 \%$. All results presented below represent $27 \mathrm{~d}$ of simulation in order to achieve steady-state conditions.

\section{RESULTS AND DISCUSSION}

\section{Measured profiles and activities}

The model was tested on data originating from an investigation during the summer thaw in the Young Sound fjord in northeast Greenland (Rysgaard et al. 1996). Measurements were made of $\mathrm{O}_{2}, \mathrm{NH}_{4}{ }^{+}, \mathrm{NO}_{3}{ }^{-}$ and $\mathrm{TCO}_{2}\left(\mathrm{CO}_{2}+\mathrm{HCO}_{3}{ }^{-}+\mathrm{CO}_{3}{ }^{2-}\right)$ concentration profiles, as well as of porosity and the $\mathrm{C}: \mathrm{N}$ ratio within the sediment. In addition, the rates of $\mathrm{NH}_{4}{ }^{+}$production, nitrification, coupled nitrification-denitrification, denitrification based on water column $\mathrm{NO}_{3}{ }^{-}$, and sulfate reduction were measured. Finally, the net exchange rates of $\mathrm{O}_{2}, \mathrm{NH}_{4}{ }^{+}, \mathrm{NO}_{3}{ }^{-}$and $\mathrm{TCO}_{2}$ across the sedimentwater interface were measured as described in detail by Rysgaard et al. (1996).

\section{Model simulations}

As model input, we used the curved line fitted through the measured porosity data and a linear fit of the measured sulfate reduction rate within the upper $10 \mathrm{~cm}$ of the sediment (Fig. 2). Porosity was almost con-

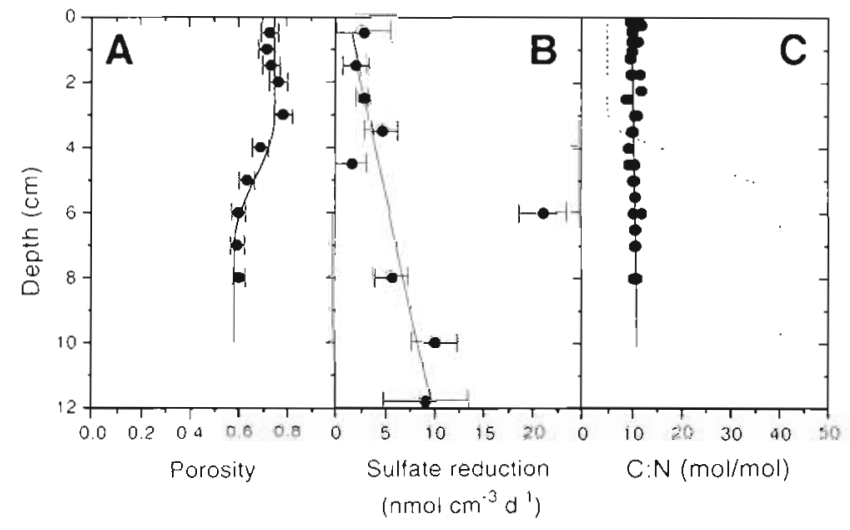

Fig. 2. (A) Porosity within the sediment. The line fitted through the measured data points was used as model input. (B) Rates of sulfate reduction with depth. The fitted line represents the sulfate reduction rate input for the model. (C) Measured total $C: N$ ratio $(\bullet)$ and the $C: N$ ratio (-.) within the biodegradable fraction of the organic matter with sediment depth. (Error bars represent $2 \mathrm{SE}$ )

stant (0.73) in the upper $3 \mathrm{~cm}$ of the sediment and then decreased below $3 \mathrm{~cm}$ to 0.58 at a depth of $8 \mathrm{~cm}$. Values for diffusivities in seawater at $0^{\circ} \mathrm{C}$ for all the solutes considered $\left(\mathrm{O}_{2}, \mathrm{NH}_{4}{ }^{+}, \mathrm{NO}_{3}{ }^{-}, \mathrm{N}_{2}, \mathrm{TCO}_{2}\right.$ and $\mathrm{H}_{2} \mathrm{~S}$; Table 1), were taken from Li \& Gregory (1974) and Broecker \& Peng (1974).

The first series of simulations was based on the measured total C:N ratio (biodegradable + non-biodegradable fraction of organic matter), which was almost constant with sediment depth (Fig. 2). Various simulations were carried out with different input parameters for the reaction rates $V_{1}, V_{2}, V_{\mathrm{d}}$, and $V_{6}$. This process was repeated until the best agreement between the simulated and measured concentration profiles was obtained. However, with the constant total $C: N$ ratio of approximately 10 , which represents both biodegradable and refractory material, it was not possible to simulate the measured $\mathrm{NH}_{4}{ }^{+}$profile, especially in the upper 3 to $4 \mathrm{~cm}$ of the sediment. These simulations resulted in too little $\mathrm{NH}_{4}{ }^{+}$being produced and an

Table 1. Molecular diffusion coefficients $(D)$ in sea water at $0^{\circ} \mathrm{C}$ of reactants. These diffusion coefficients were transformed into sediment diffusion coefficients $\left(D_{\mathrm{s}}\right)$ as described in the text

\begin{tabular}{|lc|}
\hline Reactant & $D\left(\mathrm{~cm}^{2} \mathrm{~s}^{-1}\right)$ \\
\hline $\mathrm{O}_{2}$ & $11.7 \times 10^{-6}$ \\
$\mathrm{CO}_{2}$ & $9.4 \times 10^{-6}$ \\
$\mathrm{~N}_{2}$ & $9.5 \times 10^{-6}$ \\
$\mathrm{H}_{2} \mathrm{~S}$ & $8.7 \times 10^{-6}$ \\
$\mathrm{NH}_{4}{ }^{+}$ & $9.8 \times 10^{-6}$ \\
$\mathrm{NO}_{3}^{-}$ & $9.8 \times 10^{-6}$ \\
\hline
\end{tabular}



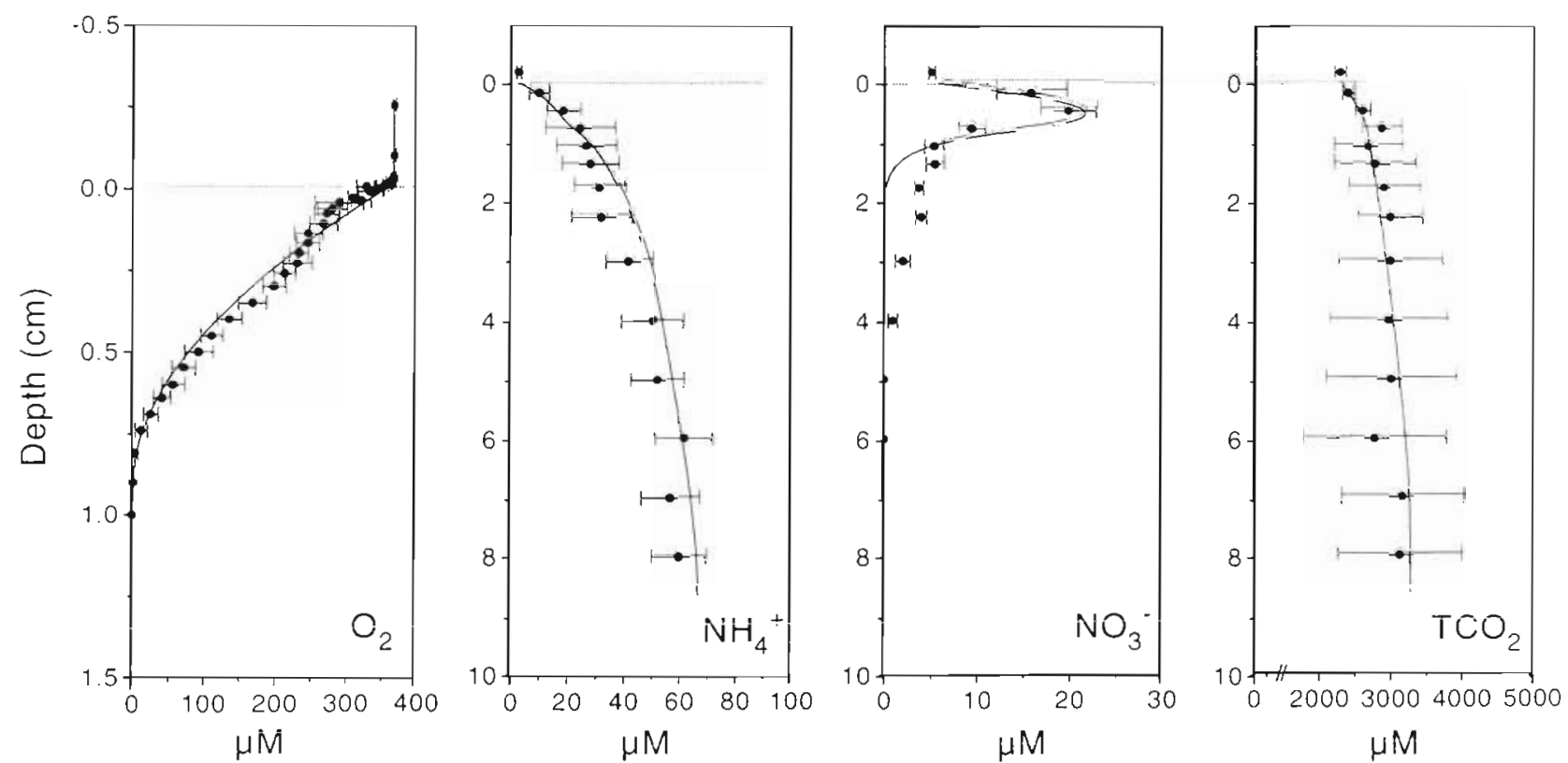

Fig. 3. Measured $(\bullet)$ and simulated $(-)$ concentration profiles of $\mathrm{O}_{2}, \mathrm{NH}_{4}{ }^{+}, \mathrm{NO}_{3}{ }^{-}$and $\mathrm{TCO}_{2}$ within the sediment, using a variable C:N ratio (5 to 40 ) and the parameters in Table 2 as input parameters for the model

underestimation of $\mathrm{NH}_{4}{ }^{+}$concentrations in this zone. A new series of simulations was then carried out involving only the $\mathrm{C}: \mathrm{N}$ ratio of the biodegradable fraction of the organic matter. The mean $\mathrm{C}: \mathrm{N}$ ratio in the upper sediment was calculated to equal 5 from the measured concentration gradient of $\mathrm{CO}_{2}$ at the sediment-water interface and the measured net $\mathrm{NH}_{4}{ }^{+}$production. Blackburn (1980) also found that the biodegradable $\mathrm{C}: \mathrm{N}$ ratio of the organic matter in the upper sediment was lower than the average $\mathrm{C}: \mathrm{N}$ of the detritus at the same depth, and that the $\mathrm{C}: \mathrm{N}$ ratio in the organic matter being mineralized increased with depth. Using this same pattern, a C:N ratio of 5 in the upper $3 \mathrm{~cm}$ of the sediment and a larger value of 40 below $6 \mathrm{~cm}$ (shown in Fig. 2 as a dashed line), gave the best agreement between all the measured and calculated concentration profiles. These profiles are shown in Fig. 3, and the final values by which the reaction rates are defined are listed in Table 2 .

In general, the model gave a good estimation of all the measured profiles within this sediment. Due to both diffusion and consumption of $\mathrm{O}_{2}$, the $\mathrm{O}_{2}$ concentration decreased from $370 \mu \mathrm{M}$ in the overlying water to 0 at approximately $0.9 \mathrm{~cm}$ depth. Mineralization of organic material in both the oxic and anoxic zones of the sediment resulted in the simulated profiles of $\mathrm{NH}_{4}{ }^{+}$ and $\mathrm{TCO}_{2}$. Within the oxic zone where both $\mathrm{NH}_{4}{ }^{+}$and $\mathrm{O}_{2}$ occurred, $\mathrm{NO}_{3}{ }^{-}$was produced by nitrification and the model accurately predicted the size and location of the $\mathrm{NO}_{3}{ }^{-}$concentration peak.

Table 2. Optimal input parameters for reaction rates. (Parameters related to $V_{d}$ are illustrated in Fig. 1.) Org-M: organic matter

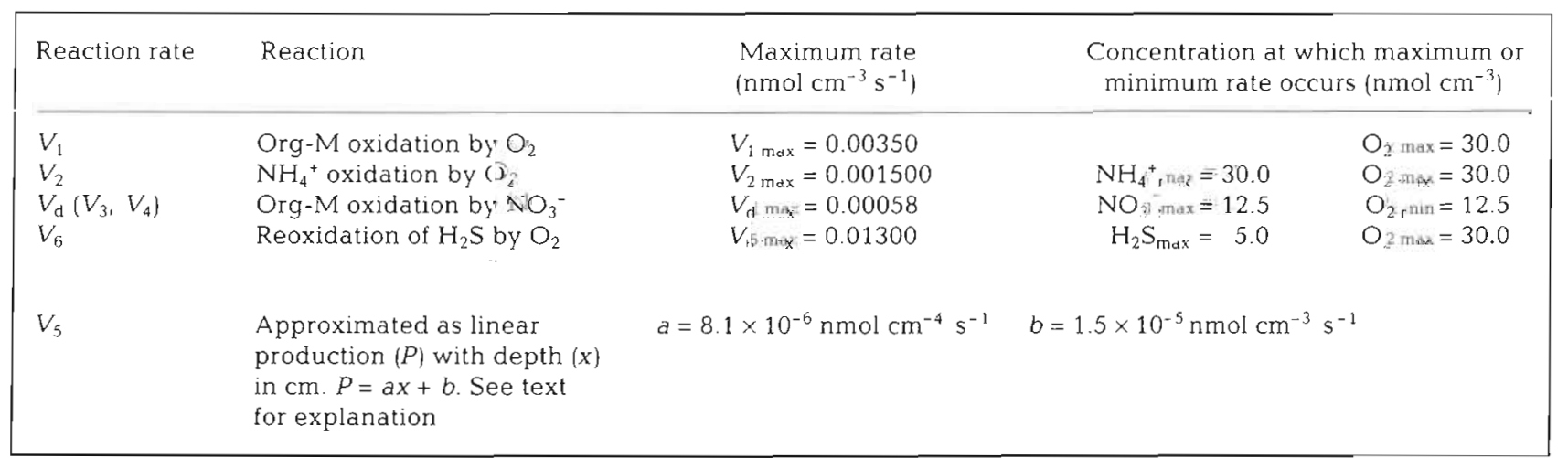


Calculated profiles of $\mathrm{O}_{2}, \mathrm{NH}_{4}{ }^{+}, \mathrm{NO}_{3}{ }^{-} \mathrm{n}^{\prime}$ $\mathrm{NO}_{3}{ }^{-}$w and $\mathrm{N}_{2}$ in the upper $2 \mathrm{~cm}$ of the sediment are illustrated in Fig. $4 \mathrm{~A}$, together with the rates of $\mathrm{O}_{2}$ consumption, $\mathrm{TCO}_{2}$ production, net $\mathrm{NH}_{4}{ }^{+}$production, $\mathrm{NO}_{3}{ }^{-} \mathrm{n}$ production (nitrification) and $\mathrm{N}_{2}$ production (denitrification of both $\mathrm{NO}_{3}^{-} \mathrm{n}+\mathrm{NO}_{3}^{-}$w) in Fig. 4B. Oxygen consumption is divided into 2 zones: an almost constant $\mathrm{O}_{2}$ consumption in the upper oxic zone, and a more rapid $\mathrm{O}_{2}$ consumption in the lower end of the oxic zone. The maximum $\mathrm{O}_{2}$ consumption in the lower oxic layer is the result of $\mathrm{O}_{2}$ consumption by nitrification and reoxidation of reduction equivalents from sulfate reduction. Rasmussen \& Jørgensen (1992) also observed a similar constant $\mathrm{O}_{2}$ consumption in the upper oxic zone and a maximum $\mathrm{O}_{2}$ consumption near the oxicanoxic interface following a spring phytoplankton bloom. They presumed that this enhanced consumption was due to a high flux of reduced products $\left(\mathrm{NH}_{4}{ }^{+}, \mathrm{Fe}^{2+}, \mathrm{H}_{2} \mathrm{~S}\right)$ diffusing upward to the oxic zone.

The simulated results showed that $\mathrm{TCO}_{2}$ production was highest and almost constant in the upper end of the oxic zone of the sediment and that this production decreased with depth. This pattern was presumably caused by a high degradation of fresh organic matter in the surface sediment following sedimentation of a phytoplankton bloom in the fjord (Rysgaard et al. 1996).

Studies of organic nitrogen mineralization in coastal sediments using ${ }^{15} \mathrm{~N}$-labeled $\mathrm{NH}_{4}{ }^{+}$have shown that the net $\mathrm{NH}_{4}{ }^{+}$mineralization is only a fraction of the total mineralization (Blackburn 1980) because a proportion of the released $\mathrm{NH}_{4}{ }^{+}$is reassimilated into bacterial biomass. Since we have not included assimilation into our model, the calculated $\mathrm{NH}_{4}{ }^{+}$production should be considered as net $\mathrm{NH}_{4}{ }^{+}$production. The simulated results show that the highest net $\mathrm{NH}_{4}{ }^{+}$production occurred close to the sediment surface and then decreased with sediment depth, in agreement with the production pattern for $\mathrm{TCO}_{2}$ and with previous measurements from coastal areas (Blackburn 1979, Blackburn 1980, Blackburn \& Henriksen 1983). Approximately $70 \%$ of the net $\mathrm{NH}_{4}{ }^{+}$production occurred in the oxic zone of the sediment.

The nitrification activity increased from the surface of the sediment to a maximum rate in the lower part of the oxic zone, where both $\mathrm{O}_{2}$ and $\mathrm{NH}_{4}{ }^{+}$were present in optimal concentrations. A similar distribution of nitrification activity has recently been measured in both freshwater and marine sediments using $\mathrm{NO}_{3}{ }^{-}$microsensors (Jensen et al. 1993, 1994, Lorentzen et al. unpubl.). Nitrate produced within the sediment oxic zone diffuses both upwards to the overlying water and downwards to the anoxic zone. In the anoxic zone, both $\mathrm{NO}_{3}{ }^{-}$from nitrification $\left(\mathrm{NO}_{3}{ }^{-}\right.$) and $\mathrm{NO}_{3}{ }^{-}$from the overlying water $\left(\mathrm{NO}_{3}{ }^{-} \mathrm{w}\right)$ were reduced to $\mathrm{N}_{2}$ by denitrifying bacteria. The maximal activity of denitrification was simulated just below the oxic zone and then decreased to zero at a depth of $2.5 \mathrm{~cm}$. The simulation of the vertical distribution of denitrification activity is in good agreement with direct measurements of denitrification using microsensor techniques (Christensen et al. 1989, Dalsgaard \& Revsbech 1992, Jensen et al. 1993). In order to get the best agreement between simulated and measured profiles, denitrification was allowed to occur up to an $\mathrm{O}_{2}$ concentration of $12 \mu \mathrm{M}$. However, it is possible that the simulated overlap in nitrification and denitrification activity is not occurring in situ but primarily reflects variations in the measured $\mathrm{O}_{2}$ penetration depth in the different sediment cores investigated. This may be because simulated results are compared with mean values of the measured concentrations.

The integrated values of the activities shown in Fig. 4B are presented in Table 3 together with the measured rates. A good agreement is found between the simulated and the measured activities of nitrification, denitrification, net $\mathrm{NH}_{4}{ }^{+}$production and the effluxes of $\mathrm{NH}_{4}{ }^{+}$and $\mathrm{NO}_{3}{ }^{-}$. 


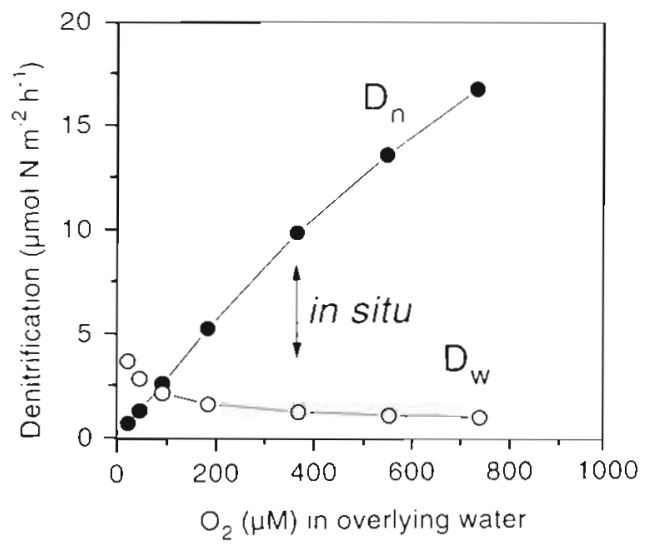

Fig. 5. Simulated rates of denitrification based on water phase $\mathrm{NO}_{3}{ }^{-}\left(D_{\mathrm{w}}\right)$ and coupled nitrification-denitrification $\left(D_{\mathrm{n}}\right)$ as a function of the $\mathrm{O}_{2}$ concentration in the overiying water. in situ data points represent in situ simulated activities

\section{Predictions with the model}

Various simulations can be performed with the model because of its general construction, and numerous changes in input parameters are possible. For example, we simulated the effect of varying the $\mathrm{O}_{2}$ concentration in the water column on denitrification (Fig. 5). The model predicts that denitrification of $\mathrm{NO}_{3}{ }^{-}$ from nitrification $\left(D_{\mathrm{n}}\right)$ increases with higher $\mathrm{O}_{2}$ concentrations in the water column while denitrification of $\mathrm{NO}_{3}{ }^{-}$from the overlying water $\left(D_{\mathrm{w}}\right)$ decreases. This pattern is in good agreement with experimental data obtained from sediment cores using ${ }^{15} \mathrm{~N}$-labeled $\mathrm{NO}_{3}{ }^{-}$ as a tracer (Rysgaard et al. 1994). In addition, the effect of increasing the $\mathrm{NO}_{3}{ }^{-}$concentration in the overlying

Table 3. Comparison between simulated and measured fluxes and activities within the sediment. The 'model output' column represents the simulation based on parameters from Table 2 and the variable $\mathrm{C}: \mathrm{N}$ ratio in Fig. 2. The 'measured' column represents mean rates of 10 intact sediment cores $(2 \times \mathrm{SE}$ in parentheses)

\begin{tabular}{|c|c|c|}
\hline Process & $\begin{array}{l}\text { Model output } \\
\text { (C:N variable) } \\
\left(\mu \mathrm{mol} \mathrm{m}^{-2} \mathrm{~h}^{-1}\right)\end{array}$ & $\begin{array}{c}\text { Measured } \\
\left(\mu \mathrm{mol} \mathrm{m}^{-2} \mathrm{~h}^{-1}\right)\end{array}$ \\
\hline $\mathrm{O}_{2}$ uptake & $1 \neq 3$ & $173^{\mathrm{d}}$ \\
\hline $\mathrm{CO}_{2}$ production & 149 & $149^{a}$ \\
\hline Net $\mathrm{NH}_{4}{ }^{+}$production & 30 & $29(10)$ \\
\hline Nitrification & 21 & $22(4)$ \\
\hline$D_{\mathrm{n}}$ & 9 & $7(3)$ \\
\hline$D_{w}$ & 1 & $2(2)$ \\
\hline Total denitrification & 10 & $9(4)$ \\
\hline $\mathrm{NH}_{4}{ }^{+}$efflux & 9 & $7(9)$ \\
\hline $\mathrm{NO}_{3}{ }^{-}$efflux & 10 & $5(4)$ \\
\hline
\end{tabular}

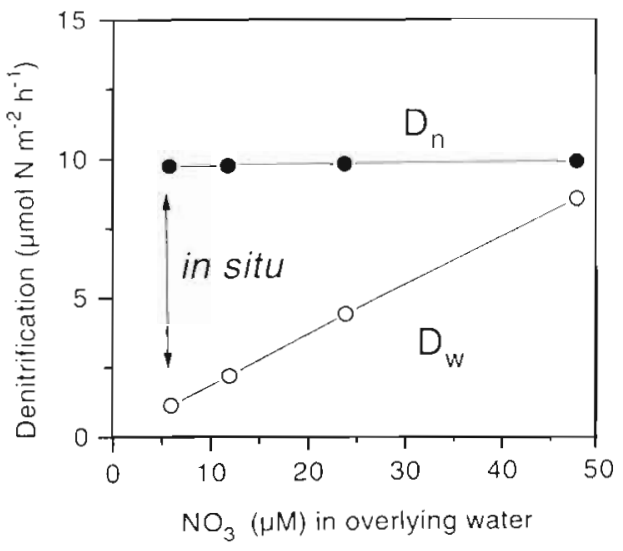

Fig. 6. Simulated rates of denitrification based on water phase $\mathrm{NO}_{3}^{-}\left(D_{\mathrm{w}}\right)$ and coupled nitrification-denitrification $\left(D_{n}\right)$ as a function of the $\mathrm{NO}_{3}{ }^{-}$concentration in the overlying water. In situ data points represent in situ simulated activities

water on denitrification was simulated (Fig. 6). The model predicts that $D_{\mathrm{w}}$ is proportional to water column $\mathrm{NO}_{3}{ }^{-}$, as has been demonstrated by Christensen \& Sørensen (1988), Risgaard-Petersen et al. (1994) and Rysgaard et al. (1995). Furthermore, $D_{\mathrm{n}}$ is unaffected by increases in water column $\mathrm{NO}_{3}{ }^{-}$, which is in agreement with results from Nielsen (1992), Pelegrí et al. (1994) and Rysgaard et al. (1995).

In conclusion, the model performed excellent simulations of the experimentally obtained profiles $\mathrm{CO}_{2}$ $\mathrm{NH}_{4}{ }^{+}, \mathrm{NO}_{3}{ }^{-}, \mathrm{TCO}_{2}$ ) and the activities of $\mathrm{O}_{2}$ consumption, net $\mathrm{NH}_{4}{ }^{+}$production, nitrification, denitrification and the fluxes of $\mathrm{NH}_{4}{ }^{+}$and $\mathrm{NO}_{3}{ }^{-}$across the sedimentwater interface. The model also successfully predicted the effect of changes in the $\mathrm{O}_{2}$ and $\mathrm{NO}_{3}{ }^{-}$concentrations in the overlying water on denitrification rates. The model is general in its application and can easily be changed or extended, which makes it an effective tool in studies of biogeochemical cycling in sediments. Finally, the model can easily be adapted to sediments of different composition or at other geographical localities.

Acknowledgements. We gratefully acknowledge fınancial support from the Carlsberg Foundation and from the Danish National Research Councils. We thank Preben Sørensen for skillful assistance both in the field and in the laboratory, and the Danish Milıtary Division, Sirnus, for their hospitality and guidance on the ice floes. Henry T Blackburn is thanked for his comments on this manuscript and Karen McGlathery for reading the manuscript.

\section{LITERATURE CITED}

Berner RA (1980) Early diagenesis. A theoretical approach. Princeton University Press, Princeton, NJ, p 39

Billen $G$ (1982) An idealized model of nitrogen recycling in marine sediments. Am J Sci 282:512-541 
Blackburn ND, Blackburn TH (1993) A reaction diffusion model of C-N-S-O species in a stratified sediment. FEMS Microbiol Ecol 102:207-215

Blackburn TH (1979) Method for measuring rates of $\mathrm{NH}_{4}{ }_{4}$ turnover in anoxic marine sediments, using a ${ }^{15} \mathrm{~N}-\mathrm{NH}_{4}{ }^{+}$ dilution technique. Appl Environ Microbiol 37:760-765

Blackburn TH (1980) Seasonal variation in the rates of organic- $\mathrm{N}$ mineralization in anoxic sediments. Colloque International CNRS (Marseille) 293:173-183

Blackburn TH, Blackburn ND, Jensen K, Risgaard-Petersen N (1994) Simulation model of the coupling between nitrification and denitrification in a freshwater sediment. Appl Environ Microbiol 60:3089-3095

Blackburn TH, Henriksen K (1983) Nitrogen cycling in different types of sediment from Danish waters. Limnol Oceanogr 28:477-493

Boudreau BP, Canfield DE, Mucci A (1992) Early diagenesis in a marine sapropel, Mangrove Lake, Bermuda. Limnol Oceanogr 37:1738-1753

Broecker WS, Peng TH (1974) Gas exchange rates between air and sea. Tellus 26:21-35

Christensen PB, Nielsen LP, Revsbech NP, Sorensen J (1989) Microzonation of denitrification activity in stream sediments as studied with a combined oxygen and nitrous oxide microsensor. Appl Environ Microbiol 55: $1234-1241$

Christensen PB, Sorensen J (1988) Denitrification in sediment of lowland streams: regional and seasonal variation in Gelbæk and Rabis bæk, Denmark. FEMS Microb Ecol 53: 335-344

Dalsgaard T, Revsbech NP (1992) Regulating factors of denitrification in trickling filter biofilms as measured with oxygen/nitrous oxide microsensor. FEMS Microbiol Ecol 101: $151-164$

Flemming RH (1940) The composition of plankton and units for reporting populations and production. Proc Pacif Sci Congr 3:535-540

Jahnke RA, Emerson SR, Murray JW (1982) A model of oxygen reduction, denitrification, and organic matter mineralization in marine sediments. Limnol Oceanogr 27:610-623

Jensen K, Revsbech NP, Nielsen LP (1993) Microscale distribution of nitrification activity in sediment determined with a shielded microsensor for nitrate. Appl Environ Microbiol 59:3287-3296

Jensen K, Sloth NS, Risgaard-Petersen N, Rysgaard S, Revsbech NP (1994) Estimation of nitrification and denitrifica-

Responsible Subject Editor: F. Thingstad, Bergen, Norway tion from microprofiles of oxygen and mutrate in model sediment systems. Appl Environ Microbiol 60:2094-2100

Li YH, Gregory S (1974) Diffusion of ions in sea water and deep-sea sediments. Geochim Cosmochim Acta 38: $703-714$

Nielsen LP (1992) Denitrification in sediment determined from nitrogen isotope pairing. FEMS Microbiol Ecol 86 $357-362$

Patankar SV (1980) Numerical heat transfer and fluid flow. McGraw Hill, New York

Pelegri SP, Nielsen LP, Blackburn TH (1994) Denitrification in estuarine sediment stimulated by the irrigation activity of the amphipod Corophium volutator. Mar Ecol Prog Ser 105:285-290

Rasmussen H, Jørgensen BB (1992) Microelectrode studies of seasonal oxygen uptake in a coastal sediment: role of molecular diffusion. Mar Ecol Prog Ser 81:289-303

Revsbech NP, Madsen B, Jørgensen BB (1986) Oxygen production and consumption in sediments determined at high spatial resolution by computer simulation of oxygen microelectrode data. Limnol Oceanogr 31:293-304

Richards FA (1965) Anoxic basins and fjords. In: Riley JP, Skirrow $G$ (eds) Chemical oceanography, Vol 1. Academic Press, New York, p 611-645

Risgaard-Petersen N, Rysgaard S, Nielsen LP, Revsbech NP (1994) Diurnal variation of denitrification and nitrification in sediments colonized by benthic microphytes. Limnol Oceanogr 39:573-579

Rysgaard S, Christensen PB, Nielsen LP (1995) Seasonal variation in nitrification and denitrification in estuarine sediment colonized by benthic microalgae and bioturbating infauna. Mar Ecol Prog Ser 126:111-121

Rysgaard S, Finster K, Dahlgaard H (1996) Primary production, nutrient dynamic and mineralization in a northeastern Greenland fjord during the summer thaw. Polar Biol $16: 497-506$

Rysgaard S, Risgaard-Petersen N, Sloth NP, Nielsen LP (1994) Oxygen regulation of nitrification and denitrification in sediments. Limnol Oceanogr 39:1643-1652

Ullman WJ, Aller RC (1982) Diffusion coefficients in nearshore marine sediments. Limnol Oceanogr 27. 552-556

Vanderborght JP, Billen G (1975) Vertical distribution of nitrate concentration in interstitial water of marine sediments with nitrification and denitrification. Limnol Oceanogr 20:953-961

Manuscript first received: March 20, 1996

Revised version accepted. October 3,1996 